\title{
Pengaruh Variasi Waktu Blanching dan Konsentrasi Asam Sitrat Terhadap Karakteristik dan Aktivitas Ekstrak Pigmen Ubi Jalar Ungu (Ipomoea batatas L.)
}

\section{Effect of The Variation of Blanching-Time and Citric Acid Concentration on Characteristics and Activities of Pigments Purple Sweet Potato (Ipomoea batatas L.) Extract}

\author{
Bella Cita Maharani $^{1)}$, Triana Lindriati ${ }^{2)}$, Nurud Diniyah ${ }^{3)}$ \\ 1) Mahasiswa Jurusan Teknologi Hasil Pertanian Fakultas Teknologi Pertanian Universitas Jember \\ 2) Laboratorium Rekayasa Proses Hasil Pertanian, Fakultas Teknologi Pertanian Universitas Jember \\ ${ }^{3)}$ Laboratorium Kimia Biokimia Hasil Pertanian , Fakultas Teknologi Pertanian Universitas Jember \\ Jln. Kalimantan 37, Kampus Tegalboto Jember 68121 \\ *E-mail : bellamaharani27@yahoo.co.id / nurud.ftp@unej.ac.id
}

\section{A R T I CLE INFO}

\section{Article history}

Received: 23 Juni 2016

Accepted: 22 Juli 2016

Available online: Februari 2017

Keywords :

Anthocyanin

Antioxidant

Extraction

purple sweet potato

Kata kunci :

Antioksidan

Antosianin

Ekstraksi

ubi jalar ungu

\begin{abstract}
The aim of this study was to determine the effect of variations in blanching time and citric acid concentration to yield, hue, $a^{*}$ (redness), pH, total anthocyanin and antioxidant activity of sweet potato extract. This reaserch used 3 factorial Randomized Block Design (RBD). Combination was repeated 3 times. Blanching was varied in three time (3, 5, and 7 minutes) and concentration of citric acid was 5,10 , and $15 \%$. The results showed that blanching time and the interaction between blanching time and addition of citric acid concentration was significantly effect on the parameters of yield, hue, a* (redness), total anthocyanin and antioxidant activity. Citric acid concentration was also significantly effect on yield, hue, a* (redness), pH, total anthocyanin and the antioxidant activity. The purple color of natural colorant product in this research have total anthocyanin colorant 69,32$190,51 \mathrm{mg} / 100 \mathrm{~g}$, and antioxidant activity 26,11-47,60\%.
\end{abstract}

\section{Pendahuluan}

Perkembangan industri pangan semakin pesat seiring dengan peningkatan kebutuhan konsumen. Kecenderungan konsumen menginginkan produk dengan penampilan yang menarik mengakibatkan semakin banyak kasus penggunaan pewarna sintetik. Pewarna sintetik cenderung lebih murah dan memberikan warna yang lebih cerah dibandingkan pewarna alami, akan tetapi pewarna sintetik mengandung logam berat seperti alumunium dan timah yang berbahaya bagi kesehatan, sehingga perlu dikembangkan pewarna makanan yang aman. Antosianin merupakan salah satu alternatif pewarna alami jenis violet g.b atau berwarna ungu yang aman bagi kesehatan (Hanum, 2000) dan dapat digunakan sebagai pewarna dalam minuman penyegar, kembang gula, produk susu, roti dan kue, produk sayuran, produk ikan, lemak dan minyak, selai, jelly, manisan, produk awetan dan sirup buah (Burdock, 1997). Antosianin adalah bagian senyawa fenol yang tergolong flavonoid. Jumlah senyawa antosianin adalah sekitar 90-96\% dari total senyawa fenol (Durst dan Wrolstad, 2005). 
Sumber pewarna alami golongan antosianin yang menjanjikan untuk dikembangkan adalah ubi jalar ungu. Produktivitas ubi jalar ungu lokal di Indonesia tergolong cukup tinggi salah satunya varietas Antin-3 yaitu sekitar 30,6 ton/ha dengan kandungan antosianin $150,67 \mathrm{mg} / 100$ g (Sinar tani, 2014). Ubi jalar ungu mengandung enzim polifenoloksidase yang dapat mengakibatkan reaksi pencoklatan secara enzimatis, reaksi tersebut dapat menyebabkan rusaknya pigmen. Alternatifuntuk mengatasi hal tersebut adalah dengan dilakukannya inaktivsi enzim dengan perlakuan blanching.Enzim polifenoloksidase aktif pada suhu ruang dan terdegradasi pada suhu diatas $70^{\circ} \mathrm{C}$ (Steed and Truong, 2008).

Etanol $95 \%$ merupakan pelarut yang umum digunakan dalam ekstraksi antosianin dikarenakan kepolaran etanol hampir sama dengan antosianin sehingga antosianin akan terlarut sempurna. Etanol sendiri merupakan pelarut organik yang bersifat tidak beracun dan tidak berwarna (Ramadhan dan Phaza, 2010) . Ekstraksi ubi jalar ungu dengan hasil yang maksimal dapat dilakukan dengan cara menambahkan asam pada pelarut etanol, salah satu jenis asam yang bisa digunakan adalah asam sitrat. Asam sitrat memiliki keunggulan dibandingkan dengan asam lainya yaitu tidak berbau, mudah ditemukan dan relatif murah.Hasil penelitian yang dilakukan oleh Tensiska dkk (2007) pada ekstraksi pigmen antosianin buah arben menunjukkan bahwa pelarut yang ditambahkan asam sitrat dapat menghasilkan total antosianin yang lebih tinggi sebesar 27,7 mg/100 g dibandingkan dengan pelarut yang sama dengan ditambahkan asam asetat yaitu sebesar 26,4 mg/100 g. Berdasarkan hal tersebut, penelitian ini perlu dilakukan untuk mencari kondisi optimum yang dapat menghasilkan rendemen dalam jumlah besar dan nilai aktivitas antioksidan yang terbaik untuk antosianin.

\section{Metodologi Penelitian}

Bahan yang digunakan pada penelitian ini adalah ubi jalar ungu (Ipomoea batatas L.), etanol (95\%), asam sitrat, buffer $\mathrm{pH} 1,0$ dan $\mathrm{pH} 4,5, \mathrm{KCl}, \mathrm{HCl}, \mathrm{Na}$-asetat, DPPH (Diphenyl picrylhydrazyl), dan aquades.

Alat penelitian terdiri atas peralatan gelas, neraca analitik (Mettler Toledo), sentrifuge, hand blender, pipet tetes, $\mathrm{pH}$ meter (Jen Way), alumunium foil, stirrer, batang stirrer, kain saring, rotary vacuum evaporator (Buchi rotavapor), penyaring vakum (Vacumbrand $M E$ 2), spektrofotometer (Genesys), mikro pipet (Gilson), colour reader Minolta CR-10, dan pignometer.
Penelitian ini dilakukan menggunakan Rancangan Acak Kelompok (RAK) faktorial dengan dua faktor dan masing-masing 3 level, sehingga didapatkan 9 kombinasi perlakuan dan diulang 3 kali. Faktor pertama yaitu waktu blanching (A) terdiri dari 3 menit (A1),5 menit (A2) dan 7 menit (A3). Faktor kedua yaitu konsentrasi asam sitrat pada pelarut etanol (B) yaitu 5\% (B1), 10\% (B2) dan 15 $\%$ (B3). Analisis yang dilakukan meliputi rendemen ekstrak pekat ubi jalar ungu (Hanum, 2000), hue (Hutchings, 1999), a* (kemerahan) (Yuwono dan Susanto, 1998), pH (Apriyantono, 1989), total antosianin metode $p H$ Differential (Steed, 2008), dan aktivitas antioksidan metode DPPH (Gadow dkk., 1997).

\section{Ekstraksi}

Ubi jalar ungu berkualitas baik dan tidak mengalami cacat disiapkan. Sampel yang diperoleh dicuci hingga bersih dan dilakukan pengecilan ukuran dengan ketebalan $\pm 2 \mathrm{~cm}$ melingkar sesuai bentuk umbi, ditimbang sebanyak 200 g, kemudian di-blanching sesuai dengan perlakuan selama 3, 5 dan 7 menit dengan menggunakan blanching uap pada suhu $70^{\circ} \mathrm{C}$. Ekstraksi antosianin ubi jalar ungu dilakukan dengan menyiapkan sampel hasil blanching dan dilakukan pengecilan ukuran dengan hand blender. Sampel yang telah hancur diekstrak menggunakan pelarut etanol yang telah ditambahkan asam sitrat $(5,10$, dan 15\%). Perbandingan antara bahan dan pelarut sebesar 1:2 (b/v) sedangkan perbandingan antara etanol dengan asam yaitu 95:5\%, 90:10\% dan 85:15\% dengan volume total sebesar $400 \mathrm{~mL}$. Pemisahan antara filtrat dan residu dilakukan dengan sentrifugasi 4000 rpm selama 10 menit. Residu yang telah dipisahkan selanjutnya diekstrak kembali dengan cara menambahkan perbandingan pelarut dan asam sitrat masing-masing sebesar 95:5\%, 90:10\% dan 85:15\%, kemudian dilakukan penggabungan filtrat. Ekstrak yang telah digabungkan selanjutnya disaring kembali dengan penyaring vaccum untuk memisahkan residu yang masih tersisa dan dievaporasi dengan vacum evaporator pada suhu $40^{\circ} \mathrm{C}$ dan tekanan $(50 / 60 \mathrm{~Hz})$ selama 5 jam hingga didapatkan ekstrak pekat yang siap dianalisis.

\section{HASIL DAN PEMBAHASAN Rendemen}

Rendemen ekstrak pekat ubi jalar ungu pada penelitian ini berkisar antara 19,58-41,31\% (Gambar 1). 


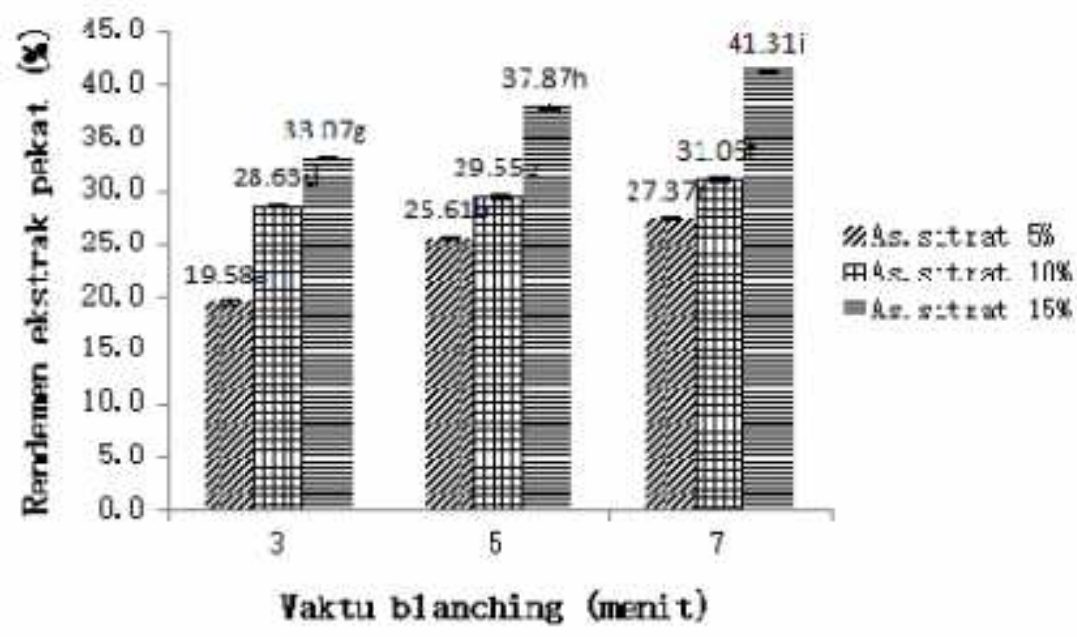

Gambar 1. Nilai Rata-RataRendemen Ekstrak Pekat Ubi Jalar Ungu Hasil Ekstraksi dengan variasi Waktu Blanching dan Konsentrasi Asam Sitrat pada Pelarut Etanol.

Analisis ragam menunjukkan bahwa perlakuan waktu blanching dan konsentrasi asam sitrat serta interaksi antar keduanya berpengaruh nyata $(\alpha 0,05)$ terhadap rendemen ekstrak pekat ubi jalar ungu. Berdasarkan Gambar 1, rendemen terendah terdapat pada perlakuan waktu blanching 3 menit dan konsentrasi asam sitrat $5 \%$ sebesar $19,58 \%$ sedangkan nilai rendemen tertinggi terdapat pada perlakuan waktu blanching 7 menit dan konsentrasi asam sitrat $15 \%$ sebesar $41,31 \%$. Rendemen ekstrak pekat antosianin ubi ungu berbanding lurus dengan lama waktu blanching dan banyaknya konsentrasi asam sitrat yang ditambahkan pada pelarut etanol. Semakin lama waktu blanching dan semakin besar penambahan konsentrasi asam sitrat pada pelarut etanol maka rendemen yang terekstrak semakin besar, hal tersebut diduga karena blanching berfungsi untuk melunakkan jaringan sel ubi jalar ungu sehingga komponen yang terekstrak juga semakin besar. Kristijarti (2012) menyatakan semakin tinggi temperatur ekstraksi maka rendemen ekstrak yang dihasilkan akan semakin besar. asam sitrat yang ditambahkan saat ekstraksi berfungsi untuk mendenaturasi sel sehingga semakin tinggi konsentrasi yang digunakan, maka semakin banyak membran sel yang terdegradasi yang mengakibatkan komponen pigmen mudah keluar dari membran dan menghasilkan rendemen yang lebih banyak. Penelitian sebelumnya juga menunjukkan bahwa ekstraksi antosianin dari kulit terong jepang menghasilkan rendemen antosianin yang semakin meningkat dengan semakin bertambahnya konsentrasi $\mathrm{HCl}$ dalam etanol dari 0,50 N ke konsentrasi HCl 1,50 N (Diniyah dkk., 2010). Ekstraksi senyawa golongan flavonoid dianjurkan dilakukan pada suasana asam karena asam berfungsi mendenaturasi membran sel tanaman (Ribonson, 1995).

\section{Warna}

Lightness (L)

Nilai lightnes (L) menunjukkan gelap terangnya warna (Winarno, 2004). Nilai lightness (L) ekstrak pekat ubi jalar ungu berkisar antara 40,80-41,25 (Gambar 2).

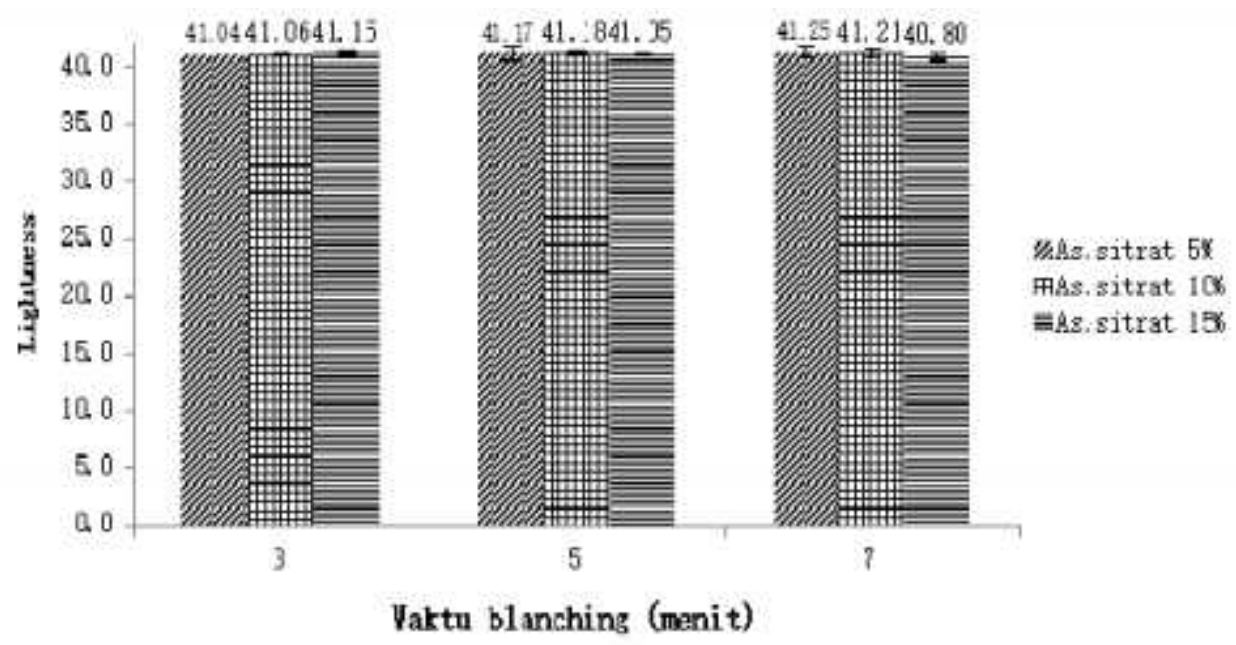

Gambar 2. Nilai Rata-Rata Lightness Ekstrak Pekat Ubi Jalar Ungu Hasil Ekstraksi dengan variasi Waktu Blanching dan Konsentrasi Asam Sitrat pada Pelarut Etanol. 
Analisis ragam menunjukkan bahwa perlakuan waktu blanching dan konsentrasi asam sitrat serta interaksi antar keduanya berpengaruh tidak nyata $(\alpha 0,05)$ terhadap lightness ekstrak pekat ubi jalar ungu. Berdasarkan Gambar 2, nilai lightness (L) terendah terdapat pada perlakuan waktu blanching 7 menit dan konsentrasi asam sitrat $15 \%$ sebesar 40,80 sedangkan nilai lightness tertinggi terdapat pada perlakuan waktu blanching 7 menit dan konsentrasi asam sitrat 5\% sebesar 41,25. Nilai lightness pada ekstrak pekat ubi jalar ungu memiliki selisih yang tidak terlalu besar, hal tersebut diduga karena perlakuan rentang waktu blanching yang tidak terlalu jauh menyebabkan nilai lightness yang tidak berbeda jauh. Nilai lightness mengalami kenaikan seiring dengan lama waktu blanching, namun hal tersebut tidak berlaku pada waktu blanching 7 menit, semakin besar konsentrasi asam sitrat mengakibatkan nilai lightness semakin menurun.

\section{Hue}

Hue digunakan untuk membedakan warna-warna dan menentukan kemerahan (redness), kehijauan (greenness) dan sebagainya dari cahaya (Hariyanto, 2009). Nilai hue pada ekstrak pekat ubi jalar ungu berkisar antara $359,02^{\circ}-359,29^{\circ}$ (Gambar 3)

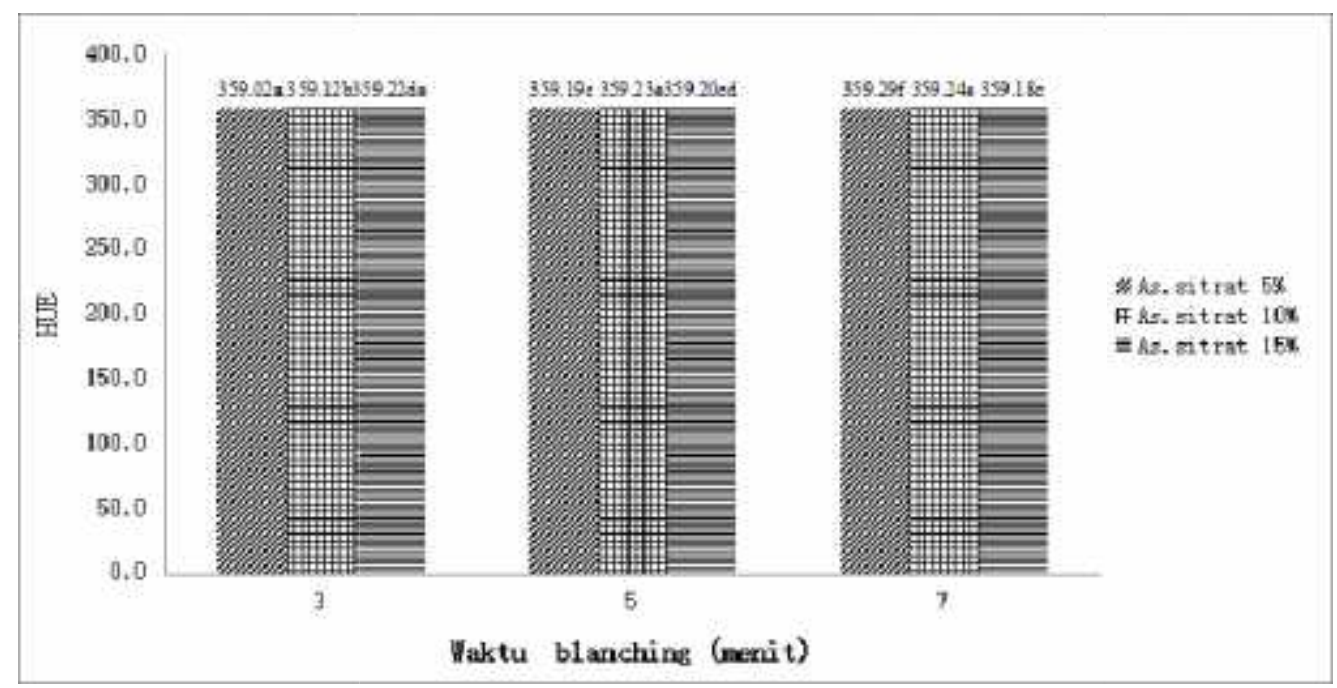

Gambar 3. Nilai Rata-Rata Hue Ekstrak Pekat Ubi Jalar Ungu Hasil Ekstraksi dengan variasi Waktu Blanching dan Konsentrasi Asam Sitrat pada Pelarut Etanol.

Analisis ragam menunjukkan bahwa perlakuan waktu blanching dan konsentrasi asam sitrat serta interaksi antar keduanya berpengaruh nyata $(\alpha 0,05)$ terhadap hue ekstrak pekat ubi jalar ungu. Berdasarkan Gambar 3, nilai hue terendah terdapat pada perlakuan waktu blanching 3 menit dan konsentrasi asam sitrat 5\% sebesar 359,02, sedangkan nilai hue tertinggi terdapat pada perlakuan waktu blanching 7 menit dan konsentrasi asam sitrat 5\% sebesar 359,29. Menurut Hutching (1999) rentang nilai hue $359,02^{\circ}-359,29^{\circ}$ termasuk warna red purple. Semakin lama waktu blanching dan semakin besar penambahan konsentrasi asam sitrat pada pelarut etanol dapat meningkatkan nilai hue pada ekstrak pekat ubi jalar ungu. Namun pada perlakuan konsentrasi asam sitrat yang semakin tinggi, yaitu $15 \%$ nilai hue cenderung menurun. Hal tersebut diduga karena asam sitrat dengan konsentrasi yang tinggi yaitu 15\% menyebabkan memudarnya warna akibat dari hidrolisis gugus gula pada antosianin menjadi aglikonnya yaitu antosianidin yang relatif kurang stabil dimana konsentrasi gula yang lebih tinggi dan adanya oksigen akan mengakibatkan kerusakan pigmen yang lebih besar (deMan, 1997) dan suhu yang semakin tinggi akan mendorong terlepasnya bagian glikosil pada antosianin dengan menghidrolisis ikatan glikosidik sehingga terbentuk aglikon tidak stabil dan antosianin kehilangan warna (Tantituvanont dkk., 2008). Keadaan tersebut diduga menjadi alasan mengapa terjadi penurunan nilai hue pada lama blanching tertentu dengan semakin besarnya konsentrasi asam sitrat.

\section{Kemerahan $\left(a^{*}\right)$}

Nilai (a*) menunjukan tingkat kemerahan dari ekstrak pekat ubi jalar ungu. nilai rata-rata $\left(a^{*}\right)$ pada ekstrak pekat ubi jalar ungu berkisar antara 10,87-19,27 (Gambar 4). 


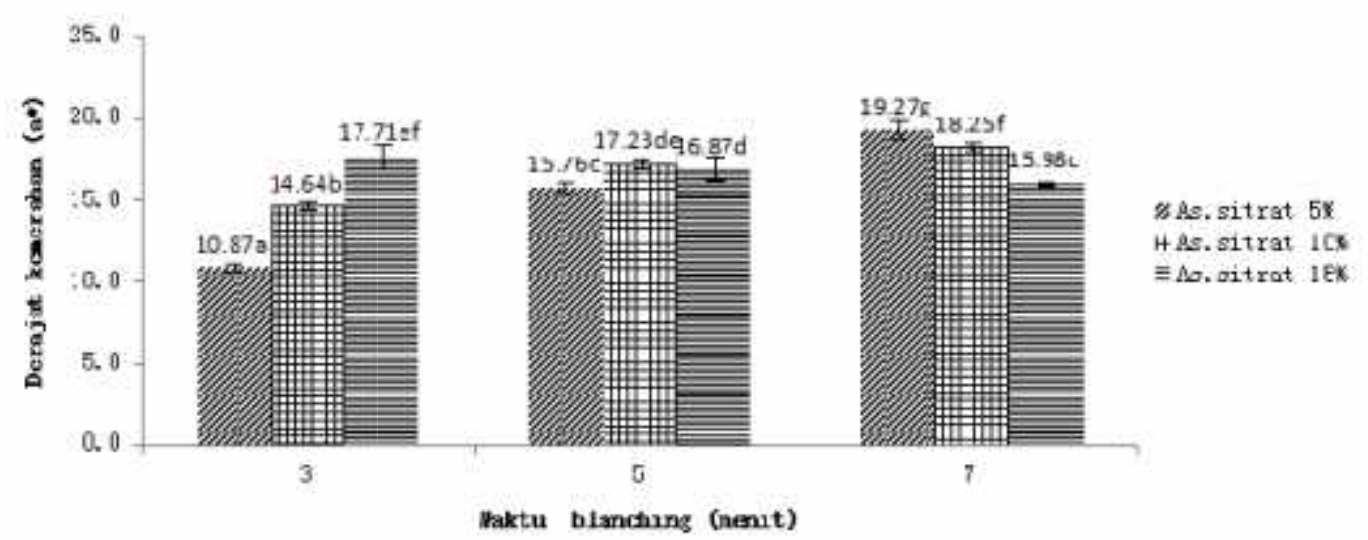

Gambar 4. Nilai Rata-Rata Kemerahan (a*) Ekstrak Pekat Ubi Jalar Ungu Hasil Ekstraksi dengan variasi Waktu Blanching dan Konsentrasi Asam Sitrat pada Pelarut Etanol.

Analisis ragam menunjukkan bahwa perlakuan waktu blanching dan konsentrasi asam sitrat serta interaksi antar keduanya berpengaruh nyata $(\alpha 0,05)$ terhadap derajat kemerahan $\left(a^{*}\right)$ ekstrak pekat ubi jalar ungu. Berdasarkan Gambar 4, nilai (a*) terendah terdapat pada perlakuan waktu blanching 3 menit dan penambahan konsentrasi asam sitrat $5 \%$ sebesar 10,87 , sedangkan nilai tertinggi terdapat pada perlakuan waktu blanching 7 menit dan konsentrasi asam sitrat 5\% sebesar 19,27. Semakin lama waktu blanching dan semakin besar konsentrasi asam sitrat pada pelarut etanol maka semakin besar pula nilai $\left(\mathrm{a}^{*}\right)$ yang dihasilkan. sesuai dengan penelitian yang dilakukan oleh Diniyah, dkk., (2010) dimana semakin tinggi konsentrasi $\mathrm{HCl}$ maka derajat kemerahan (a*) ekstrak antosianin terung semakin meningkat. Konsentrasi asam sitrat yang semakin meningkat yaitu $15 \%$ menyebabkan derajat kemerahan (a*) cenderung menurun seiring dengan semakin lamanya waktu blanching, hal tersebut diduga karena terjadi hidrolisis gugus gula pada antosianin menjadi aglikonnya yaitu antosianidin yang relatif kurang stabil.

\section{pH}

Nilai rata-rata $\mathrm{pH}$ pada ekstrak pekat ubi jalar ungu berkisar anatara 3,7-4,46 (Gambar 5).

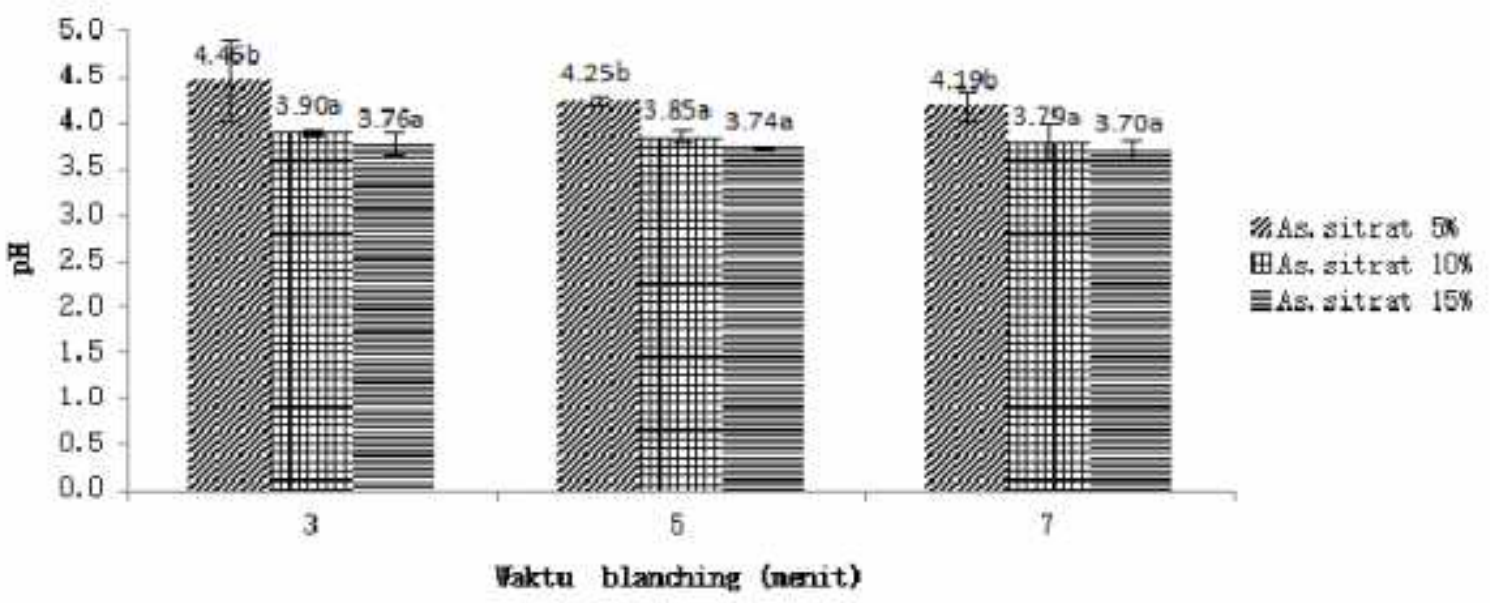

Gambar 5. Nilai Rata-Rata pH Ekstrak Pekat Ubi Jalar Ungu Hasil Ekstraksi dengan variasi Waktu Blanching dan Konsentrasi Asam Sitrat pada Pelarut Etanol.

Analisis ragam menunjukkan bahwa perlakuan waktu blanching berpengaruh tidak nyata terhadap ekstrak pekat ubi jalar ungu, sedangkan konsentrasi asam sitrat memberikan pengaruh nyata, interaksi antar kedua perlakuan berpengaruh tidak nyata $(\alpha 0,05)$ terhadap $\mathrm{pH}$ ekstrak pekat ubi jalar ungu. BerdasarkanGambar 5, nilai $\mathrm{pH}$ terendah terdapat pada perlakuan waktu blanching 7 menit dan konsentrasi asam sitrat $15 \%$ sebesar 3,70, sedangkan nilai $\mathrm{pH}$ tertinggi terdapat pada perlakuan waktu blanching 3 menit dan penambahan konsentrasi asam sitrat $5 \%$ sebesar 4,46 . Konsentrasi asam sitrat yang semakin tinggi dapat menurunkan $\mathrm{pH}$ pada ekstrak pekat ubi jalar ungu, hal tersebut sesuai dengan pendapat yang dikemukakan oleh Corlett dan Brown (1980) yang menyatakan bahwa semakin tinggi tingkat keasaman suatu asam pada larutan maka semakin besar tendensi untuk melepaskan proton (ion $\mathrm{H}^{+}$) sehingga $\mathrm{pH}$ menjadi turun. Penambahan jenis asam dapat berpengaruh terhadap lingkungan $\mathrm{pH}$ rendah yang dapat merubah pewarna semakin baik dan $\mathrm{pH}$ yang tinggi akan membuat 
pewarna semakin tidak baik (Sukardjo, 1991). pH ekstrak pekat ubi jalar ungu berhubungan dengan stabilitas antosianin, semakin rendah $\mathrm{pH}$ maka stabilitas ekstrak semakin tinggi sehingga antosianin yang dihasilkan semakin besar.

\section{Total antosianin}

Rata-rata total antosianin pada ekstrak pekat ubi jalar ungu berkisar antara 0,90-2,51 (mg/100g) (Gambar $6)$.

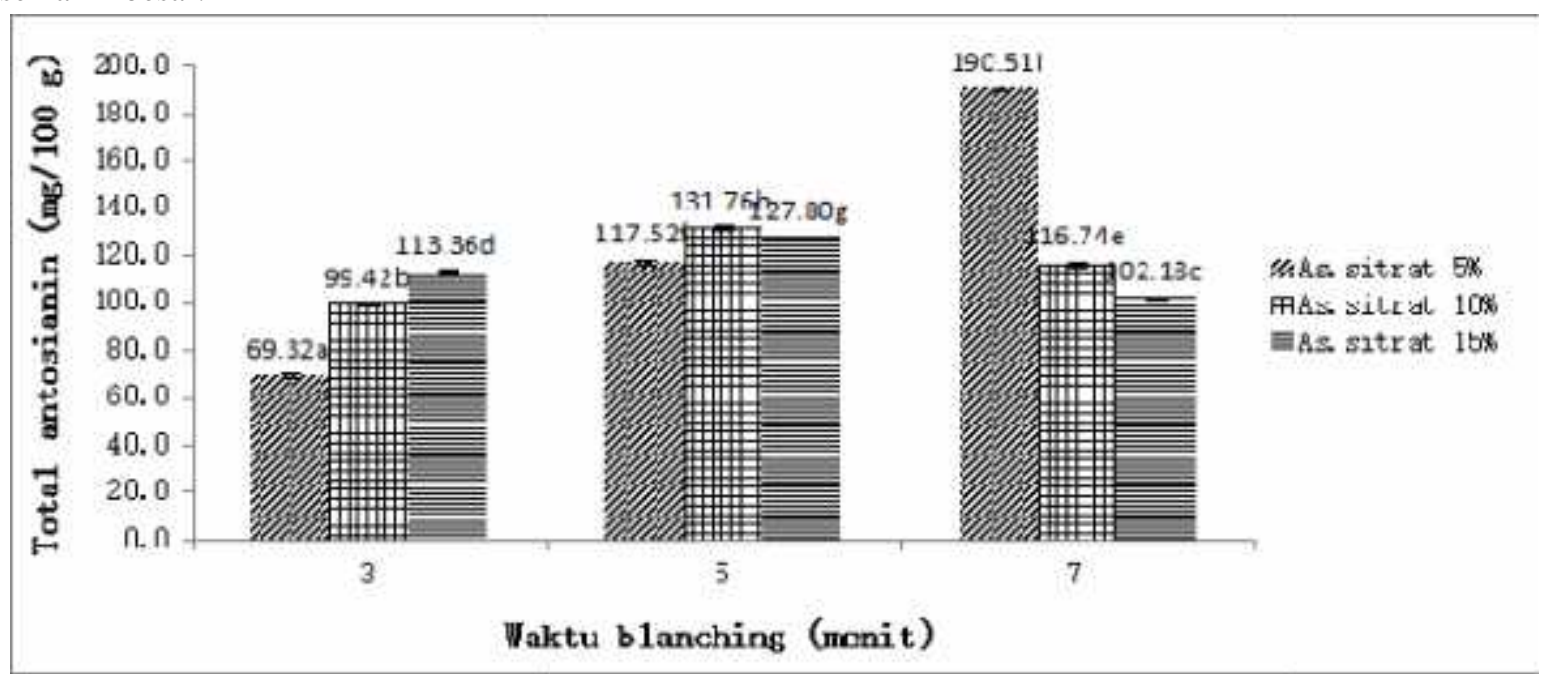

Gambar 6. Nilai Rata-Rata Total Antosianin Ekstrak Pekat Ubi Jalar Ungu Hasil Ekstraksi dengan variasi Waktu Blanching dan Konsentrasi Asam Sitrat pada Pelarut Etanol.

Analisis ragam menunjukkan bahwa perlakuan waktu blanching dan konsentrasi asam sitrat serta interaksi antar keduanya berpengaruh nyata $(\alpha 0,05)$ terhadap total antosianin ekstrak pekat ubi jalar ungu. Berdasarkan Gambar 6, diketahui bahwa total antosianin terendah terdapat pada perlakuan waktu blanching 3 menit dan konsentrasi asam sitrat 5\% sebesar 69,32 (mg/100g), sedangkan total antosianin tertinggi terdapat pada perlakuan waktu blanching 7 menit dan konsentrasi asam sitrat sebesar 5\% sebesar 190,51 (mg/100g). Waktu blanching dan konsentrasi asam sitrat berbanding lurus dengan total antosianin yang dihasilkan. Menurut Fennema (1996) penambahan asam sitrat pada saat ekstraksi dapat menurunkan $\mathrm{pH}$ atau membuat kondisi lebih asam .Semakin asam ( $\mathrm{pH}$ rendah) menyebabkan semakin banyaknya pigmen antosianin berada dalam bentuk kation flavilium atau oxonium yang berwarna dan pengukuran absorbansi akan menunjukan jumlah antosianin yang semakin besar. Pendapat tersebut diperkuat oleh Tensiska (2007) yang menyatakan bahwa keadaan yang semakin asam juga menyebabkan semakin banyak dinding sel vakuola yang pecah sehingga pigmen antosianin semakin banyak yang terekstrak. Blanching dengan waktutertentu dan peningkatan konsentrasi asam justru menurunkan kandungan antosianin ekstrak pekat ubi jalar ungu, hal tersebut diduga karena terjadi hidrolisis gugus gula pada antosianin menjadi aglikonnya yaitu antosianidin yang relatif kurang stabil. Menurut deMan
(1997), konsentrasi gula yang lebih tinggi dan adanya oksigen akan mengakibatkan kerusakan pigmen yang lebih besar. Pendapat tersebut juga didukung oleh Sudarmanto dkk (1990) yang menyatakan bahwa beberapa faktor yang mempengaruhi laju kerusakan antosianin selain lama penyimpanan dan suhu yang tinggi, peningkatan kadar gula juga akan mengurangi kandungan pigmen.
Aktivitas Antioksidan
Nilai rata-rata aktivitas antioksidan pada ekstrak pekat ubi jalar ungu berkisar antara 26,11-47,60\% (Gambar 7). Analisis ragam menunjukkan bahwa perlakuan waktu blanching dan konsentrasi asam sitrat serta interaksi antar keduanya berpengaruh nyata $(\alpha 0,05)$ terhadap aktivitas antioksidan ekstrak pekat ubi jalar ungu. Berdasarkan Gambar 7, aktivitas antioksidan terendah terdapat pada perlakuan waktu blanching 7 menit dan konsentrasi asam sitrat $15 \%$ sebesar $26,11 \%$, sedangkan aktivitas antioksidan tertinggi terdapat pada perlakuan waktu blanching 7 menit dan asam sitrat 5\% sebesar 47,60\%. Antioksidan merupakan komponen yang mampu menghambat proses oksidasi yang memicu reaksi ketengikan dan kerusakan bahan pangan (Brown, 2009). Nilai aktivitas antioksidan hampir seiring dengan data pengamatan antosianin, hal tersebut disebabkan karena sumber antioksidan utama dari ekstrak pekat ubi jalar ungu adalah antosianin. 


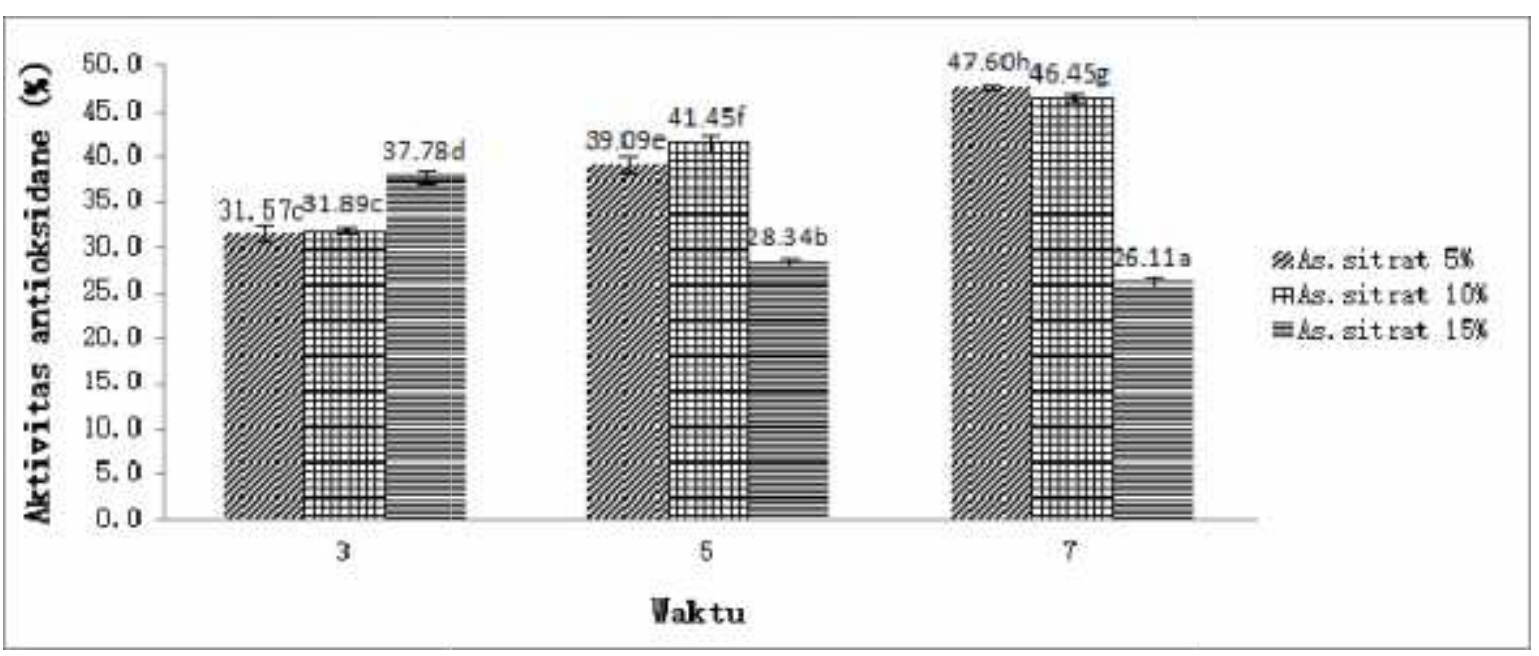

Gambar 7. Nilai Rata-Rata Aktivitas Antioksidan Ekstrak Pekat Ubi Jalar Ungu Hasil Ekstraksi dengan variasi Waktu Blanching dan Konsentrasi Asam Sitrat pada Pelarut Etanol.

\section{KESIMPULAN DAN SARAN}

Hasil penelitian menunjukkan bahwa waktu blanchingdan interaksi antara waktu blanching dan konsentrasi asam sitratberpengaruh nyata terhadap rendemen, hue, derajat kemerahan $\left(\mathrm{a}^{*}\right)$, total antosianin dan aktivitas antioksidan. Konsentrasi asam sitrat juga berpengaruh nyata terhadap rendemen, hue, $\left(\mathrm{a}^{*}\right), \mathrm{pH}$, total antosianin dan aktivitas antioksidan. Rentang total antosianin pada penelitian ini berkisar antara 69,32$190,51 \mathrm{mg} / 100 \mathrm{~g}$, dan aktivitas antioksidan berkisar antara $26,11-47,60 \%$.

\section{DAFTAR PUSTAKA}

Burdock, G. A. 1997. Encyclopedia of Food and Colour Additives. CRC Press. New York. pp. 17481749.

Corrlett, D. A. dan Brown, M. H. 1980. pH and Acidity dalam Microbial Biology Of Food. Volume I. Academic Press. New York.

DeMan dan John M. 1997. Kimia Makanan. Diterjemahkan oleh Kosasih. Penerbit ITB : Bandung.

Diniyah, N., Susanto. T., dan Nisa, F.C. 2010. Kajian Ekstraksi Antosianin Kulit Terung Jepang (Solanum melongena L). Teknotan, 7 (2), Fakultas Teknologi Industri Pertanian Universitas Padjadjaran dan PERTETA PATPI Cabang Bandung Bandung.1007-1012.

Fellows, P. 1990. Dehydration. In Encyclopedia of Food Science and Technology. Volume 1. Jhon Wiley and Sons, Inc.New York

Fennema, O.R. 1996. Food Chemistry. Marcell Dekker Food. Volume I. Academic Press. New York.

Hanum, T. 2000. Ekstraksi dan Stabilitas Zat Pewarna Alami dari Katul Beras Ketan Hitam (Oryza sativa glutinosa). Buletin Teknologi dan Industri Pangan XI(1), Departemen Pertanian. Bogor. 17-23.
Hutching, J.B. 1999. Food Color and Apearance. Aspen publisher Inc., Marylan.

Kristijarti A.P, dan Ariestya A. 2012. 1solasi Zat Warna Ungu pada Ipomoea batatas Poir dengan Pelarut Air. Lembaga Penelitian dan Pengabdian kepada Masyarakat. Bandung. Universitas Katolik Prahayangan.

Kukuh Yudiono. 2011. Ekstraksi Antosianin dari Ubi Jalar Ungu (Ipomoea batatas cv. Ayamurasaki) dengan Teknik Ekstraksi Subcritical Water. Jurusan Teknologi Hasil Pertanian Universitas Katolik Widya Karya Malang. Malang.

Rahmawati F. 2008. Pengaruh vitamin C terhadap aktivitas polifenol oksidase buah Apel merah (Pyrus malus) secara in vitro [skripsi]. Surakarta. Universitas Muhammadiyah Surakarta

Ramadhan, A. E dan H.A. Phaza. 2010. Pengaruh Konsentrasi Etanol, Suhu dan Jumlah stage ada EkstraksiOleoresin Jahe (Zingiber officinale rosc) secara Batch. Semarang. Universitas Diponegoro.

Saati, E.A. 2002. Potensi Bunga Pacar Air (Impatiens Balsamina Linn.) sebagai Pewarna Alami pada Produk Minuman. Majalah Tropika. Vol. 10 (2).

Sinar tani. 2014. Saatnya mengklarifikasikan promosi ubi jalar.

http://m.tabloidsinartani.com/index.php?id=148\&t x_ttnews[tt_news]=1434\&cHash=c9b2df7610afe6 84c79c5ff707ced32d. [Diakses tanggal 29 Desember 2015]

Sudarmanto. 1990. Bahan Pewarna Alami dalam Tanaman Pangan. PAU Pangan dan Gizi. Yogyakarta. UGM.

Sukardjo. 1990. Kimia Fisika. Rineka Cipta. Yogyakarta Tantituvanont A, Werawatganone P, Jiamchaisri P, Manopakdee K. 2008. Preparation and stability of butterfly pea color extract loaded in 
microparticles prepared by spray drying. Thai J. Pharm. Sci.,32:59-69.

Tensiska, E. Sukarminah, D. Natalia. 2007. Ekstraksi Pewarna Dari Buah Arben (Rubus idaeus (Linn.) dan Aplikasinya dalam Sistem Pangan. Jurnal Tekno dan Industry Pangan, Vol. XVIII No. 1 Th. 2007.

Weningtyas, H. 2009. Efek pencampuran ekstrak zat warna kayu secang dengan beberapa sumber antosianin terhadap kualitas warna merah dan sifat antioksidannya .Skripsi. Fakultas Teknologi Pertanian Institut Pertanian Bogor. Bogor.

Wrolstad, R.E., Durst, R.W. dan Lee, J. 2005. Tracking color and pigment changes in anthocyanin products.Trends in Food Science and Technology 16: 433-428.

Yuwono, S.S dan Susanto T. 1998. Pengujian Fisik Pangan. Fakultas Teknologi Pertanian. Universitas Brawijaya. Malang. 